\title{
SOCIAL INFRASTRUCTURE SERVICES AS A FACTOR OF THE ECONOMIC DEVELOPMENT OF SOUTH OSSETIA DURING THE PERIOD OF THE PLANNED AND ADMINISTRATIVE ECONOMIC SYSTEM ${ }^{1}$
}

\author{
() Irina K. Dzhioeva, Nodar G. Caberty, Albert V. Techov \\ South Ossetian State University, Tskhinvali, Republic of South Ossetia; \\ North Ossetian State University, Vladikavkaz, Republic of North Ossetia-Alania, \\ Russian Federation djioeva_irina@mail.ru, kaberti-n@mail.ru, albert.texov@mail.ru
}

\begin{abstract}
Considering the opinion of a number of scientists, the revolutionary explosion in 1917 was not so much a natural change of economic formations, as a form of resolving the most acute contradictions of Russian society in the socio-economic sphere. One of the main contradictions was the lag of Russia from industrialized countries both in the direction of the development of technology and labor productivity and the general culture of the population. It is justified that the development of infrastructure services sector during the period of the planned economy contributed to economic growth and was important in solving the strategic tasks of the country's economic development for the effective use of material and labor resources, since insufficient level of its development is a significant deterrent to achieving economic growth, which requires state policy strengthening in relation to infrastructure services sector. Objects of social and household infrastructure create opportunities to meet both the biological needs of a person for creation of conditions for his survival as a member of a social community, and from the point of view of his existence and realization as a person. The formation of these minimal needs and the process of their implementation in relation to the Soviet period are insufficiently studied, which is explained by certain socio-economic reasons, one of which is disregard for the social needs of a person. The study of the socio-economic needs of the population, including in the dynamics of its development, is necessary for the more complete understanding of the social policy of the Soviet state, and determining the degree of its influence on the daily life of the people.

Key words: social sphere, income of the population, the presence of imbalances, socio-economic situation, essential commodities.
\end{abstract}

[И.К. Джиоева, Н.Г. Каберты, А.В. Техов Услуги социальной инфраструктуры как фактор развития экономики Южной Осетии в период планово-административной системы хозяйствования]

Учитывая мнение ряда ученых, революционный взрыв в 1917 г. был не столько закономерной сменой экономических формаций, сколько формой разрешения острейших противоречий российского общества в социально-экономической сфере. Одним из основных противоречий было отставание России от индустриально развитых стран как в направлении развития технологий, так и производительности труда и общей культуры населения. Обосновывается положение, что развитие сферы инфрраструктурных услуг в период плановой экономики способствовало обеспечению экономического роста и имело важное значение в решении стратегических задач развития экономики страны для эффективного использовании материальных и трудовых ресурсов, поскольку, недостаточный уровень ее развития является существенным сдерживающим фактором в достижении экономического роста, а это требует усиления государственной политики по отношению к сфере инфраструктурных услуг. Объекты социально-бытовой инфраструктуры создают возможности для удовлетворения как биологических потребностей человека для создания условий его выживания как члена социальной общно-

${ }^{1}$ The article was prepared within the framework of the project No. 20-510-07003 of the Ministry of Education and Science of the Republic of South Ossetia_a "The development of the agricultural sector as a factor of improving the standard of living and migration attractiveness of the Republic of South Ossetia" supported by the Russian Humanitarian Research Foundation.

Статья подготовлена в рамках поддержанного РГНФ проекта № 20-510-07003 МОН РЮО_а «Развитие аграрного сектора как фактора повышения уровня жизни и миграционной привлекательности Республики Южная Осетия». 
сти, и с точки зрения его существования и реализации как личности. Формирование этих минимальных потребностей и процесс их реализации применительно к советскому периоду изучены недостаточно подробно, что объясняется определенными социально-экономическими причинами, одной из которых является пренебрежение к социальным потребностям человека. Исследование социальноэкономических потребностей населения, в том числе в динамике ее развития, необходимо для более полного понимания социальной политики советского государства, выяснения степени его влияния на повседневную жизнь народа.

Ключевые слова: социальная сфера, доходы населения, наличие диспропорций, социальноэкономическое положение, товары первой необходимости.

Irina K. Dzhioeva - Ph.D. in Economics, Associate Professor, South Ossetian State University, Tskhinvali, Republic of South Ossetia.

Nodar G. Koberti - Ph.D. in Economics, Associate Professor, North Ossetian State University, Vladikavkaz, Republic of North Ossetia, Russian Federation.

Albert V. Techov - Ph.D. in Economics, Associate Professor, South Ossetian State University, Tskhinvali, Republic of South Ossetia.

Джиоева Ирина Константиновна - кандидат экономических наук, дочент, Юго-Осетинский государственный университет, г. Цхинвал, Республика Южная Осетия.

Коберти Нодар Гаврилович - кандидат экономических наук, доцент, Северо-Осетинский государственный университет, г. Владикавказ, Республика Северная Осетия, Российская Федерация.

Техов Альберт Васильевич - кандидат экономических наук, доцент, Юго-Осетинский государственный университет, г. Цхинвал, Республика Южная Осетия.

The impact of the social sphere on the effectiveness of the entire reproduction process is essential for economic science and practice. This can be explained by the fact that production and social infrastructure, contributing to the creation of a common productive environment in a single reproduction activity, are of paramount importance in solving the strategic tasks of developing the country's economy and effective usage of material and labor resources. At the same time, it is important to balance the development of basic production and infrastructure, both production and social. The development of the economy of the study period shows that if the growth of main production is not supported by the expansion of all components of infrastructure, deceleration of scientific and technological progress, a decrease in the efficiency of capital investments, a drop in output and a decrease in the standard of living of the country's population begin [1, p. 35].

As is known, in the first post-war years, the main way to increase real incomes of the population was a systematic decrease in state consumer prices, while the real level of incomes of all segments of the population, including those with fixed monetary incomes, increased, the purchasing power of the ruble strengthened.

On September 1, 1957, the tax-free minimum income was increased from 250 to 370 rubles per month [14]. In general, wages of workers and employees had increased by $30 \%$ [25]. Over the next four years, the poor were completely exempt from taxation [12]. Since the first half of the $1980^{\text {s }}$, the consumption fund had not provided the necessary level of average wages and the corresponding to it wage fund. The consequence of this was an equalization, when differences in the earnings of workers turned out to be less than differences in their work. This inevitably led to a drop in interest, the employee became estranged not only from the means of production, but also from the results and the process of work itself.

In the eighth, and especially ninth, five-year plans, regular centralized measures were carried out to increase wages, associated with the introduction of a minimum of 70 rubles per month. From 1965 to 1970, the average monthly wage increased significantly - by $22 \%$ in Georgia and by $13 \%$ in South Ossetia and amounted to 96.5 rubles [3, p. 244]. 
In 1976, the average monthly wage growth was $19 \%$ in Georgia, and in South Ossetia $-2.6 \%$. The highest level of average monthly wages was observed in 1979 , when its value reached 196,1 rubles in Georgia, 134 rubles in South Ossetia. This is not only the evidence of a rapid increase in this standard of living of the population, but also of the structural features of the employed labor resources of the region mentioned above. The faster growth of real incomes of the population of South Ossetia in relation to the republican indicators is also noteworthy. The largest upswing is observed in 1975 compared to 1965: in South Ossetia - 226\%, in Georgia $160 \%$. In the future, in the $70^{\text {s }}$, the growth of real incomes of the population of South Ossetia was more stable and closer on the pace to the indicators of Georgia. In 1978-1979 in Georgia 119 and 117\%, in South Ossetia, respectively, 110 and $112 \%[17$, p. $89 ; 3$, p. 244].

In the analyzed period, according to the regional statistical office of the South Ossetian Autonomous Region, the total population was over one hundred thousand people. In working age, there were more than fifty percent of the population (in $1980-$ 51.45 thousand people, and in 1988, respectively, 52.4 thousand people), in 1988, there were 27.7 thousand children under 15 years old in the region, only 16.5 thousand people older than working age.

Table 1

\section{Availability and employment of labour resources South Ossetian Autonomous Okrug (people)*}

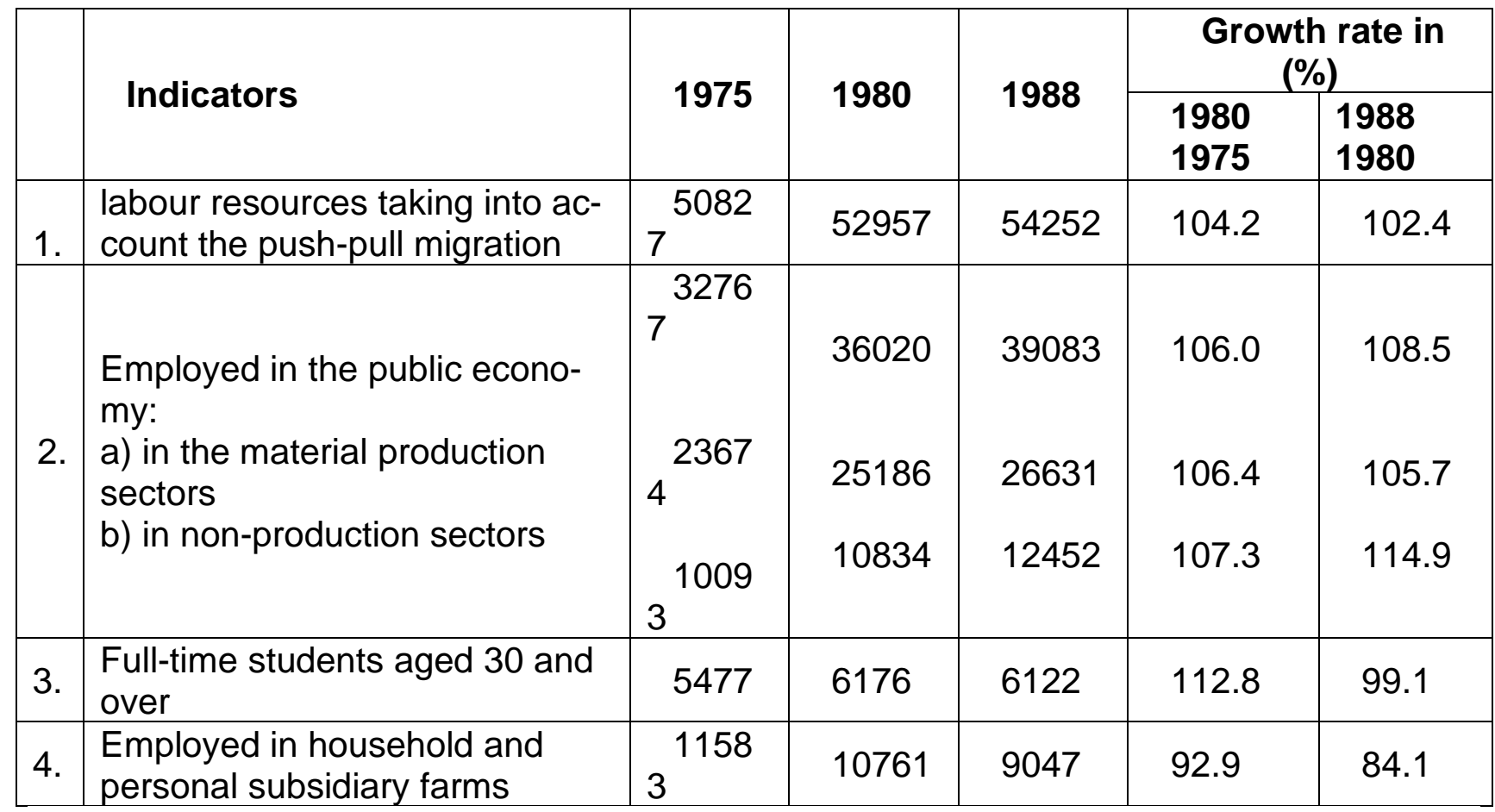

The table is compiled according to the regional statistical office of the South Ossetian Autonomous Region

Labour resources growth declined by 2.2 percent in 1988 compared to 1980 (Table 1). The largest number of workers, 26,631 people, was concentrated in the material production sectors, 12,452 people in the non-production sectors, 9047 people were employed in household and personal subsidiary farms.

One thousand eight hundred and twenty people graduated from Vocational Technical Schools. In South Ossetia, the system of vocational technical education began to 
be introduced much later than in Russia and did not last long. In 1991, they ceased to exist.

The growth of specialists in the national economy had also led to changes in their distribution among industries. The analysis of these trends reveals the following features: the number of engineers increased at the fastest pace during the study period. In 1975, 1021 people were employed in the national economic complex of South Ossetia, and in 1985 - 3250 people. During the same period, the number of economists increased by 1.8 times, 1.6 times - agronomists, livestock experts, veterinarians and foresters, 1.8 times doctors and other specialists. At the same time, the number of personnel who received vocational secondary education was growing. This made it possible in industry as a whole to increase the number of skilled workers during this period by 2.5 times, in agriculture by 1.8 times, in the sectors of non-material production by 1.5 times [17, pp. 75-78].

This trend towards the growth of specialists with higher and secondary education suggested the need to take it into account in the near term when developing a scientifically based concept of economic and social development of the entire region.

In order to replenish personnel in agricultural production, a correspondence branch of the Tbilisi Agricultural Institute functioned in Tskhinvali, with a contingent of 297 students. The existence of such a form of education played a great role, since during this period there were only 19 agronomists and livestock technicians with higher education and 113 people with secondary specialized education in agriculture. Moreover, in all collective farms of the Dzhávskii region during this period there was neither specialists with higher nor with secondary specialized education [23 p. 78,135]. The number of specialists with higher and secondary specialized education, employed in the national economy of South Ossetia in 1970 was 6 thousand people, in Abkhazia - 25.1 thousand people, and in Adjara - 198 thousand. Among them there were 3.7 thousand people with higher education in South Ossetia, 12.8 thousand people in Abkhazia, 10.2 thousand people in Adjara. Among 3.7 thousand people with higher education there were 324 engineers, 221 agronomists, 107 economists, 164 specialists of other specialties. The number of doctors of all specialties in South Ossetia in 1940 was 66, and in 1965 - 196 people. In the $80^{\text {th }}$ year, the number of doctors reached 549 people, and the number of average medical personnel -1370 people [17, p. 111].

In the study period, a relatively small decrease in the number of employees was noted in the complex of industries combining housing and public services and non-production types of consumer services. The number of people engaged in health care, education, culture, art had noticeably increased. In 1988, 3.4 million rubles were allocated for the development of the non-production sector for South Ossetia. The average monthly wage of workers and employees in the region was 160.3 rubles, compared to 148.2 rubles in 1985 [16].

The most important characteristic of living standards is the growth of consumer consumption, which is largely reflected in the indicators of retail trade.

During the study period, trade indicators improved significantly. The volume of retail turnover of state and cooperative trade for 1960-1970 was increased by 18.8 million rubles. The area of sales outlets in 1970 was 14,783 square meters [20, p. 93]. The retail turnover in South Ossetia by the end of the study period was 400 rubles (225 rubles less than the average in Georgia).

The average annual number of retail and public service workers reached 869 in 1960, and 1821 in 1970 [24]. However, the increase in retail turnover did not reach the full realization of monetary resources. As a result, plans for public bank deposits were significantly exceeded. The proportions between deposits and inventories changed in favor of the former. In 1988, the population of South Ossetia contributed 12.5 million rubles to Sberbank institutions, or $12.4 \%$ more than in 1985 [16]. 
Deposits of the population in South Ossetia had exceeded inventories by 3.3 times by the end of 1970 . The absolute value of the average deposit in South Ossetia was 1350 rubles, in Georgia - 1625 rubles, in the former USSR - 1029 rubles [26]. However, given the scarcity of some essential goods in the $1970^{\mathrm{s}}$, the prevalence of cash stocks over inventories was not normal. During 1975-1985, the growth of retail turnover increased almost doubled in South Ossetia (Table 2).

Table 2

\section{Retail turnover of state and cooperative trade (including catering)}

\begin{tabular}{|l|c|l|l|l|l|l|l|}
\hline \multirow{2}{*}{} & \multirow{2}{*}{$\begin{array}{c}\text { Total retail } \\
\text { turnover }\end{array}$} & \multicolumn{2}{|c|}{\begin{tabular}{c}
\multicolumn{2}{c|}{ state and } \\
cooperative trade
\end{tabular}} & \multicolumn{2}{c|}{$\begin{array}{c}\text { retail turnover } \\
\text { trade and catering }\end{array}$} & \multicolumn{2}{c|}{$\begin{array}{c}\text { trade in cities } \\
\text { and rural areas }\end{array}$} \\
\cline { 3 - 8 } & state & $\begin{array}{c}\text { cooperative } \\
\text { trade }\end{array}$ & $\begin{array}{c}\text { retail } \\
\text { turnover } \\
\text { trade }\end{array}$ & catering & in cities & in rural areas \\
\hline 1970 & 39.9 & 21.2 & 18.7 & 35.0 & 4.5 & 21.2 & 18.7 \\
\hline 1975 & 54.8 & 31.2 & 23.6 & 48.5 & 6.3 & 39.2 & 15.6 \\
\hline 1980 & 64.2 & 37.8 & 26.4 & 56.5 & 7.7 & 48.1 & 16.1 \\
\hline 1985 & 75.6 & 45.7 & 29.9 & 66.7 & 8.9 & 56.9 & 18.7 \\
\hline
\end{tabular}

Compiled by [26, p. 95; 17, p. 101,]

During the study period the total volume of trade turnover was dominated by state trade, the growth rate of which was ahead of the increase in trade turnover of cooperation. The share of catering almost doubled, but remained low, not reaching $10 \%$. The total volume of trade turnover was dominated by urban trade, the share of which had exceeded the rural one by almost 3.5 times by the end of the study period.

Retail turnover per capita in South Ossetia was relatively low compared to Georgia, where it amounted to 665 rubles per year. The reason for this low indicator is that the rural population of South Ossetia covered part of the food needs from income from personal subsidiary farms. In addition, trade shortages affected. Insufficiently studied demand and the presence of imbalances in the structure of trade turnover did not allow to fully realize monetary income. As a result, the plans for deposits of the population to savings banks were significantly exceeded, the proportions between deposits and inventories changed in favor of the former [25]. This phenomenon is also characteristic of South Ossetia. The number of deposits in the savings banks of South Ossetia in 1970 was 30,100 , and in $1985-58,800$, that is, increased by 28,700 . The number of deposits was 26630 thousand rubles in 1970 and 114897 thousand rubles in 1985 . The average amount of deposits over these years increased from 884 to 1954 rubles [26, p. 94], which is generally more than in Georgia.

The important indicator for assessing the development of trade is the structure of trade turnover, the ratio of food and non-food products in it (Table 3).

The given data indicate that there were practically no progressive changes in the structure of the trade turnover, more than that, in 1970 the share of non-food products was $1 \%$ higher than the final result. 


\section{Ratio of food products to non-food in the total volume of trade of the state} and cooperative trade, including catering (\%)*

\begin{tabular}{|l|l|l|l|l|}
\hline & $\mathbf{1 9 7 0}$ & $\mathbf{1 9 7 5}$ & $\mathbf{1 9 8 0}$ & $\mathbf{1 9 8 5}$ \\
\hline All products & 100 & 100 & 100 & 100 \\
\hline including: & & & & \\
food products & 44 & 48 & 46 & 45 \\
non-food products & 56 & 52 & 54 & 55 \\
\hline
\end{tabular}

Compiled by [17, p.95]

Consumer services were not at the proper level. In 1965, the number of enterprises, including ateliers was 114, and in 1970 - 175, but more than $90 \%$ of them were small enterprises; only 8 large consumer services facilities functioned in South Ossetia as a whole and 4 of them were in the city of Tskhinvali. The volume of sale of consumer services to the population in 1965 amounted to 408 thousand rubles, and it had reached 964 thousand rubles by 1970 year, 608 people [2] had been working in this area by the end of the eighth five-year plan. In rural areas, consumer services began to operate only by the end of the eighth five-year plan and the service was at a very low level, but again, everything depended on the financial capabilities of the region.

The number of consumer service enterprises had amounted to 210 by 1985 . Among them there were 135 enterprises in rural areas. The volume of sale of consumer services to the population in 1985 reached 2824 thousand rubles (in comparable prices in 1981), that is twice as much as in 1970. The average annual number of workers in this area was 1,050 people, but this branch of the social sphere lagged behind the needs of the population and still needed significant improvement.

\section{Лumepamypa}

1. Антонюк В.С. Социальная инфраструктура в составе региональной инфраструктуры / В.С. Антонюк А.Ж. Буликеева// Вестник Тюменского государственного университета.2013. № 11. С. 31-39.

2. Архив Юго-Осетинского обкома партии. Дело № 5 протокол № 14.

3. Арчвадзе Г. Экономика Советской Грузии / Г. Арчвадзе. Тбилиси. 1974. 274 с.

4. Бурис Э. Полномочия советских городских властей: Жилье, контроль за миграцией и градостроительство в Риге (1955-1959 гг.). [Электронный ресурс] URL:

http://www.perspectivia.net/content/publikationen/shdp/bourhis_polnomochiia (20.0 1.2015) (дата обращения: 28.08.2020).

5. Вавулинская Л.И. Жилищное строительство в годы «оттепели» // Научные ведомости Белгородского государственного университета. 2016. № 15. [Электронный ресурс]. URL: https: //cyberleninka.ru/article/n/zhilischnoe-stroitelstvo-vgody-ottepeli-novatsii-i-problemy-na-materialah-karelii (дата обращения: 28.08.2020).

6. Вельможко И.Н. Социальная трансформация в период хрущевской «оттепели»/ И.H. Вельможко. [Электронный ресурc] URL: https://cyberleninka.ru/article/n/sotsialnye-transformatsii-v-period-hruschevskoyottepeli (дата обращения: 27.08.2020). 
7. Гасанов М.А. Развитие отраслей производственной инфраструктуры после Октябрьской революции. [Электронный ресурc] URL: https://cyberleninka.ru/article/n/razvitie-otrasley-proizvodstvennoy-infrastrukturyposle-oktyabrskoy-revolyutsii-istoricheskiy-aspekt-i-perspektivy-formirovaniya (дата обращения).

8. Геллер М.Я. История России 1917-1996 / М.Я. Геллер, А. Некрич. в 4-х т. т.2. 1996. $225 \mathrm{c}$.

9. Горлов В.Н. Изменения жизненных ценностей советских людей при решении жилищной проблемы в 1950-е 1960-е годы // Вестник Московского государственного областного университета, 2015. № 1. С. 55-62.

10. Григорьева А.Г. Решение жилищной проблемы советских граждан в годы «оттепели» // Теория и практика общественного развития, 2010. № 4. С. 239-241. [Электронный ресурc] URL: http://teOria-practica.ru/-4-2010/istOriya/grigOreva.pdf(дата обращения: 28.08.2020).

11. Гуменюк А.А. Эволюция социальной политики советского государства во второй половине 1950-х середины 1980-х годов. [Электронный ресурc]. URL: https://cyberleninka.ru/article/n/evolyutsiya-sotsialnoy-politiki-sovetskogo-

gosudarstva-vo-vtoroy-polovine-1950-h-seredine-1980-h-gg (дата обращения: 30.08.2020).

12. Закон СССР от 14.07.1956 "О государственных пенсиях". [Электронный ресурс] URL: https://3ekc.ru/wp-content/uploads/2018/06/ZakonOPensiyah_14_07_1956.pdf (дата обращения: 27.08.2020).

13. Зворыкин В.В. Роль наследия советской инфраструктуры в кооперации экономических субъектов современной России. [Электронный ресурс]. Режим доступа https://cyberleninka.ru/article/n/rol-naslediya-sovetskoy-infrastruktury-vkooperatsii-ekonomicheskih-subektov-sovremennoy-rossii (дата обращения 30.08.2020).

14. Иванова Г.М. Проблема материального благосостояния СССР и стратегия национального реформирования в 50-е годы. [Электронный ресурс] Режим доступа: https://cyberleninka.ru/article/n/problema-materialnogo-blagosostoyaniyanaseleniya-sssr-i-strategiya-sotsialnogo-reformirovaniya-v-1950-egody/viewer(дата обращения: 27.08.2020).

15. Итоги выполнения государственного плана экономического и социального развития Юго-Осетии в1988 году: Статсборник. Цхинвали, 1989. 64с.

16. Итоги выполнения государственного плана экономического и социального развития Юго-Осетии в 1988 году // Статистический сборник. Цхинвали, 1989 г. $78 \mathrm{c}$.

17. Народное хозяйство Юго-Осетинской АО. 1922-1982 гг. Цхинвал, 1983. 140 с.

18. Постановление ЦК КПСС от 6.06. 1956 года «Об отмене платы за обучение в старших классах средних школ, в средних специальных и высших учебных заведениях СССР». [Электронный ресурс] Режим доступа: https://zen.yandex.ru/media/id/5c0d9aae9ba2f700aa08062f/otmena-platy-zaobuchenie-v-sssr-5ec01da938e7d258172a59b2 (дата обращения: 27.08.2020).

19. Постановление ЦК КПСС, Совмина СССР О развитии жилищного строительства. [Электронный ресурс] Режим доступа: https://knowhistory.ru/date/7/31/v1957-godu-prinyato-postanovlenie-o-razvitii-zhilishchnogo-stroitelstva-v-sssr (дата обращения: 27.08.2020).

20. Постановление ЦК КПСС, Совмина СССР от 19.04.1957 О государственных займах, размещаемых по подписке среди трудящихся Советского Союза". [Электронный ресурс] Режим доступа: http://docs2.cntd.ru/document/765714023 (дата обращения: 27.08.2020). 
21. Президиум ЦК КПСС. 1954-1964. [Электронный ресурc] URL: https://archive.org/details/sbornik_zakonov_sssr_i_ukazov_prezidiuma_verhovnogo soveta_sssr_1938_iiul_1956_gg (дата обращения: 30.08.2020).

22. Президиум ЦК КПССС. 1954-1964. Черновые протокольные записи заседаний. Стенограммы. Постановления. Т. 2. С. 174. [Электронный ресуpc] URL: http://sovdoc.rusarchives.ru/elib/prezidium-ck-kpss-1954-1964-volume2/files/assets/basic-html/index.html\#7 (дата обращения: 30.08.2020).

23. Развитие народного хозяйства и культуры Юго-Осетинской автономной области. Сборник документов и материалов (1956-1965 гг.). T.V. 324 с.

24. Сборник законов СССР и Указов и Президиума Верховного Совета СССР (1938 г. ноябрь 1958 г.). М., 1959. С. 506.

25. Шестаков В.А. Социально-экономическая политика советского государства в 50-е - середине 60-х годов. М. 2006. 285 с.

26. Юго-Осетия в цифрах в XI пятилетке: Статсборник. Цхинвали, 1987. 124 с.

\section{References}

1. Antonyuk V.S. Sotsialnaia infrastruktura v sostave regionalnoi infrastruktury [Social infrastructure as part of a regional infrastructure]. V.S. Antonyuk A.Zh. Bulikeeva. Bulletin of University of Tyumen 2013. No. 11. pp. 31-39 (in Russian).

2. Arkhiv lugo-Osetinskogo obkoma partii [Archive of the South Ossetian Regional Party Committee]. Case No. 5 Minutes No. 14 (in Russian).

3. Archvadze G. Ekonomika Sovetskoi Gruzii [Economics of Soviet Georgia]. G. Archvadze. Tbilisi. 1974. 274 p. (in Russian).

4. Buris E. Powers of the Soviet city authorities: Housing, migration control and urban planning in Riga (1955-1959). Available at: http://www.perspectivia.net/content/publikationen/shdp/bourhis_polnomochiia (20.01.2015) (accessed 28 August 2020).

5. Vavulinskaya L.I. Housing construction during the years of the Thaw. Scientific journal of Belgorod State University. 2016. No. 15. Available at: https: //cyberleninka.ru/article/n/zhilischnoe-stroitelstvo-v-gody-ottepeli-novatsii-iproblemy-na-materialah-karelii (accessed 28 August 2020).

6. 6. Velmozhko I.N. Social transformation during the Khrushchev Thaw. I.N. Velmozhko. Available at: https://cyberleninka.ru/article/n/sotsialnye-transformatsii-vperiod-hruschevskoy-ottepeli (accessed 27 August 2020).

7. Gasanov M.A. Development of industries of production infrastructure after the October Revolution. Available at: https://cyberleninka.ru/article/n/razvitie-otrasleyproizvodstvennoy-infrastruktury-posle-oktyabrskoy-revolyutsii-istoricheskiy-aspekti-perspektivy-formirovaniya

8. Geller M.Ya. Istoriia Rossii 1917-1996 [History of Russia 1917-1996]. M.Ya. Geller, A. Nekrich. In 4 volumes. V. 2. 1996. 225 p. (in Russian).

9. Gorlov V.N. Izmeneniia zhiznennykh tsennostei sovetskikh liudei pri reshenii zhilishchnoi problemy v 1950-e 1960-e gody. Vestnik Moskovskogo gosudarstvennogo oblastnogo universiteta [Changes in the vital values of Soviet people when solving the housing problem in the $1950^{\mathrm{s}}$ and $1960^{\mathrm{s}}$. Bulletin of Moscow State Regional University], 2015. No. 1, pp. 55-62 (in Russian).

10. Grigorieva A.G. Solving the housing problem of Soviet citizens during the thaw years. Theory and practice of social development, 2010. No. 4, pp. 239-241. Available at: http://teOria-practica.ru/-4-2010/istOriya/grigOreva.pdf (accessed 28 August 2020). 
11. Gumenyuk A.A. The evolution of the social policy of the Soviet state in the second half of the 1950s and mid-1980s. Available at: https://cyberleninka.ru/article/n/evolyutsiya-sotsialnoy-politiki-sovetskogogosudarstva-vo-vtoroy-polovine-1950-h-seredine-1980-h-gg (accessed 30 August 2020).

12.USSR Law of 14.07.1956 "On State Pensions." Available at: https://3ekc.ru/wpcontent/uploads/2018/06/ZakonOPensiyah_14_07_1956.pdf (accessed 27 August 2020).

13.Zvorykin V.V. The role of the legacy of Soviet infrastructure in the cooperation of economic entities of modern Russia. Available at: https://cyberleninka.ru/article/n/rolnaslediya-sovetskoy-infrastruktury-v-kooperatsii-ekonomicheskih-subektovsovremennoy-rossii (accessed 30 August 2020).

14. Ivanova G.M. The problem of material well-being of the USSR and the strategy of national reform in the $50^{\mathrm{s}}$. Available at: https://cyberleninka.ru/article/n/problemamaterialnogo-blagosostoyaniya-naseleniya-sssr-i-strategiya-sotsialnogoreformirovaniya-v-1950-e-gody/viewer (accessed 27 August 2020).

15. Itogi vypolneniia gosudarstvennogo plana ekonomicheskogo i sotsialnogo razvitiia lugo-Osetii v1988 godu: Statsbornik [The results of the implementation of the state plan for economic and social development of South Ossetia in 1998: Statistical book]. Tskhinvali, 1989. 64 p. (in Russian).

16. Itogi vypolneniia gosudarstvennogo plana ekonomicheskogo i sotsialnogo razvitiia lugo-Osetii v 1988 godu. Statisticheskii sbornik [The results of the implementation of the state plan for economic and social development of South Ossetia in 1988. Statistical book]. Tskhinvali, 1989. 78 p. (in Russian).

17. Narodnoe khoziaistvo lugo-Osetinskoi AO [National economy of the South Ossetian Autonomous Okrug]. 1922-1982 Tskhinvali, 1983. 140 p. (in Russian).

18. Decree of the Central Committee of the CPSU of 6.06.1956 "On the abolition of tuition fees in high schools, in secondary specialized and higher educational institutions of the USSR." Available at:

https://zen.yandex.ru/media/id/5c0d9aae9ba2f700aa08062f/otmena-platy-zaobuchenie-v-sssr-5ec01da938e7d258172a59b2 (accessed 27 August 2020).

19. Decree of the Central Committee of the CPSU, Council of Ministers of the USSR "On the Development of Housing". Available at: https://knowhistory.ru/date/7/31/v1957-godu-prinyato-postanovlenie-o-razvitii-zhilishchnogo-stroitelstva-v-sssr (accessed 27 August 2020).

20. Decree of the Central Committee of the CPSU, the Council of Ministers of the USSR from 19.04.1957 "On public loans placed by subscription among workers of the Soviet Union." Available at: http://docs2.cntd.ru/document/765714023 (accessed 27 August 2020).

21. Presidium of the Central Committee of the CPSU. 1954-1964. Available at: https://archive.org/details/sbornik_zakonov_sssr_i_ukazov_prezidiuma_verhovnog o_soveta_sssr_1938_iiul_1956_gg (accessed 30 August 2020).

22. Presidium of the Central Committee of the CPSU. 1954-1964. Draft minutes of meetings. Transcripts. Regulations. V. 2. 174 p. Available at: http://sovdoc.rusarchives.ru/elib/prezidium-ck-kpss-1954-1964-volume2/files/assets/basic-html/index.html\#7 (accessed 30 August 2020).

23. Razvitie narodnogo khoziaistva i kultury lugo-Osetinskoi avtonomnoi oblasti. Sbornik dokumentov i materialov [Development of the national economy and culture of the South Ossetian Autonomous Region. Collection of documents and materials] (1956-1965). V. 5. 324 p. (in Russian). 
24. Sbornik zakonov SSSR i Ukazov i Prezidiuma Verkhovnogo Soveta SSSR [Collection of laws of the USSR and Decrees and the Presidium of the Supreme Soviet of the USSR] (1938 November 1958). Moscow, 1959. 506 p. (in Russian).

25. Shestakov V.A. otsialno-ekonomicheskaia politika sovetskogo gosudarstva v 50-e - seredine 60-kh godov [The socio-economic policy of the Soviet state in the $50^{\mathrm{s}}$ mid-60s]. Moscow, 2006. 285 p. (in Russian).

26. Yugo-Osetiia v tsifrakh v XI piatiletke: Statsbornik [South Ossetia in numbers in the XI five-year plan: Statistical book]. Tskhinvali, 1987. 124 p. (in Russian). 